\section{Recent Acquisitions at the Natural History Museum}

The Entomological Department of the British Museum (Natural History) has recently acquired the collection of the economically important Thysanoptera, or thrips, formed by Dr. R. S. Bagnall, comprising more than 17,000 specimens, of which about 430 are types and 750 paratypes. Some 8000 insects of various orders, but mainly Diptera, have been collected for the Department in the High Tatra Mountains in Poland and Czechoslovakia by Miss D. Aubertin and Miss E. Trewavas. The King of the Hedjaz, Nejd, and its Dependencies has presented to the Geological Department the collection of fossils made by Mr. H. St. J. Philby on his recent remarkable journey in Central Arabia. It includes invertebrates from the Jurassic rocks of the Tuwaiq plateau and the Cretaceous rocks of the Arma plateau, near Riyadh, the Wahabi capital. From the area south of the Gulf of Bahrein, invertebrates of Miocene age, closely resembling those of contemporaneous rocks in the Persian oilfields, were obtained; while freshwater shells found in abundance at several localities in the middle of the great Rub' al Khali Desert show that rivers or lakes existed recently in that now arid region. The Government Geologist of the AngloEgyptian Sudan has presented a series of shells of Lower Tertiary age preserved in a remarkable kind of flint; these are the first fossils, other than a few plant remains, to be found in that territory. A large selection of material from the meteorite craters discovered in 1931 near Henbury, Central Australia, has been acquired for the Department of Minerals from the Kyancutta Museum, South Australia. This includes 172 pieces of meteoric iron with a total weight of $604 \mathrm{lb}$. The largest piece of $292 \mathrm{lb}$. was found in contact with three other masses (total weight $440 \mathrm{lb}$.) at a depth of 7 feet in the smallest of the thirteen craters. This is the only meteorite that has ever been excavated from inside a meteorite crater.

\section{Additions to the Botanical Collections}

Mrss E. Hombersley has given to the Department of Botany of the Natural History Museum 882 paintings of British flowering plants by Miss Ellen Hawkins, who died in 1864. The paintings are of considerable merit and are accompanied by descriptions, written on the opposite page of the double sheet, which give interesting details and information. Miss Hawkins wrote the botanical appendix to Robertson's "Handbook to the Peak" (1854). Mr. Reginald Cory has presented the original manuscript and drawings of the "Tabular Distribution of the Vegetable Kingdom" by John Stuart, third Earl of Bute. The Department already possesses many plants purchased at the Earl of Bute's sale in 1794. Prof. John Percival has presented a set of all the known species of AEgilops. Prof. Percival's knowledge of this difficult genus of grasses makes the set of special value. Among the purchases there is a further set of H. J. Schlieben's Tanganyika plants and 668 Brazilian and Mexican plants collected by $\mathrm{Y}$. Mexia and 248 drawings of liverworts (Jubuleæ) by Fr. Verdoorn.

\section{Epidemic Diseases in Residential Schools}

There has been since August a slight rise (which was anticipated) in the incidence of an epidemic disease of the nervous system named poliomyelitis (an infection which may sometimes result in 'infant paralysis'), though up to the present the cases have as a whole appeared singly and widely scattered. The Ministry of Health has, however, received certain inquiries as to the wisdom or expediency of closing residential schools in which such isolated cases may have occurred. The Ministry of Health is definitely of the opinion that the balance of advantage is in favour of not closing a residential school in which poliomyelitis has appeared. If the school be closed, any potential infectiousness of the disease is more widely distributed, and passes beyond such means of supervision and control as are furnished in a well-equipped residential school conducted on hygienic lines.

\section{Co-operation of Scientific Societies}

MANCHESTER chemical societies have initiated a form of co-operation which should prove of considerable value both to their members and to local industry generally. The Manchester and district sections of the Institute of Chemistry, the Society of Chemical Industry, the Society of Dyers and Colourists, the Oil and Colour Chemists' Association and the Institute of Rubber Industry, together with the Manchester Literary and Philosophical Society, have established a Joint Advisory Committee, consisting of the honorary secretaries (or other representative) of the societies concerned, in order that problems of mutual interest can be discussed and common plans arranged, and to provide a means whereby Manchester chemical opinion can be ascertained and expressed. The Committee has already published a card calendar of meetings, both scientific and social, of the participating societies, and a booklet which gives lists of officers as well as syllabuses and other information concerning the session's activities. The Chemical Society, not being organised in local sections, does not participate directly in the scheme, but - as is indicated in the booklet-fellows of that society may, under a co-operative arrangement, read papers on pure chemistry before the local section of the Society of Chemical Industry. Members of one society are cordially invited to attend meetings of any other society; hence by the promotion of personal contact and by the provision of facilities for discussion and joint action, Manchester chemists are effecting a consolidation of their own interests as well as providing an interesting experiment which will probably be found worthy of wider application. The Association of Secretaries of Technical Societies in Glasgow has also issued a programme of the meetings of the chemical and engineering societies in that city.

\section{Musk Rat Menace}

The Trustees of the British Museum had under consideration at their meeting at the Natural History Museum on October 22 the serious position in the

No. 3287, Vol. 130] 
country in relation to the musk rat menace, and particularly to the fact that now that the keeping of musk rats is prohibited except under the strictest regulations against their escape, the musk rat farmers have turned their attention to the coypu or nutria, an aquatic South American rodent. The latter animal is as large as a beaver, but has a tapering tail ; it lives in burrows, and its fur is brown, soft and dense. The Trustees decided to recommend to the authorities concerned that the nutria should, like the musk rat, be scheduled as an animal the import of which is prohibited and which shall be kept only under licence.

\section{Bartholomew Diaz off Cape Colony}

Mr. S. A. Mumford, of Tresta, Farley, Salisbury, Wilts., has written stating that the voyage of Bartholomew Diaz, when he touched the south coast of Cape Colony, is usually quoted as having taken place between August 1486 and December 1487, whereas in our "Calendar of Geographical Discovery" (NATURE, vol. 129, p. 177, Jan. 30, 1932), a note on the voyage appears under the date Feb. 3, 1488. The date given in our columns is based on a marginal note, probably by Christopher Columbus himself, on folio 13 of a copy of Pierre D'Ailly's "Imago Mundi", which fixes Diaz's return to Lisbon in the month of December 1488. The writer says he was present at Diaz's interview with the King of Portugal when the explorer's chart was shown and discussed. The "Imago Mundi" is at present in the Colombina at Seville.

\section{Announcements}

THE De Morgan medal of the London Mathematical Society, which is awarded triennially, has this year been awarded to Bertrand Russell in recognition of his mathematical work. The medal will be presented at the annual general meeting of the Society which will be held at Burlington House, Piccadilly, London, W.I, on November 10 , at 5 P.M.

AT the annual statutory meeting of the Royal Society of Edinburgh held on October 24, the following Council was elected: President: Sir E. A. Sharpey-Schafer; Vice-Presidents : Prof. J. H. Ashworth ; Dr. A. Logan Turner ; Dr. J. B. Clark ; Prof. James Ritchie; Sir Thomas Holland; The Hon. Lord Sands; General Secretary : Prof. R. A. Sampson; Secretaries to Ordinary Meetings: Prof. C. G. Darwin and Prof. F. A. E. Crew ; Treasurer : Dr. James Watt; Curator of Library and Museum : Prof. D'Arcy W. Thompson; Councillors: Dr. Murray Macgregor; Dr. A. Crichton Mitchell; Prof. P. T. Herring; Prof. James P. Kendall; Prof. T. M. MacRobert ; Prof. Godfrey H. Thomson; Dr. Malcolm Wilson; Prof. E. B. Bailey; Prof. J. C. Brash ; Prof. A. J. Clark ; Prof. A. G. Ogilvie; Prof. E. M. Wedderburn.

Prof. E. N. DA. C. Andrade will give four lectures at the Royal Institution on Tuesdays at 5.15 P.M. beginning November 1 on "Rays and Radiations".
The course is an experiment in the treatment of a branch of modern physical science on the lines of the popular Christmas Lectures to juveniles, but Prof. Andrade will address himself on this occasion to the grown-ups. He will talk and show experiments on the gamma and ultra-violet radiations, $\mathrm{X}$-rays, infra-red rays, and the particle radiations which have been used in the investigation of the inner structure of the atom. Prof. Lancelot Hogben will give three lectures, also on Tuesdays at 5.15 P.M., beginning November 29, on "Colour Change in Animals". The mechanism of colour change in such a well-known example as the chameleon will be discussed, and compared with that in other animals subject to colour changes, such as the frog, the salamander and certain fishes.

The Council of the Institution of Civil Engineers has awarded the Indian Premium for the session 1931-32 to Sir Bernard D'O. Darley (Bahawalpur, Punjab), and the Webb Prize for the session to Mr. B. G. White (London) for papers read and discussed at ordinary meetings of the Institution. The following awards for the session have been made for "Selected Engineering Papers", published without discussion :A Telford Gold Medal to Dr. J. F. Baker (Abbots Langley); Telford Premiums to Mr. William Muirhead (London), Mr. E. B. Cocks (London), Dr. James Orr (Glasgow), Dr. W. J. Walker (Johannesburg), and Mr. W. C. Ash (Vizagapatam, India); and a Crampton Prize to Mr. L. St. C. Rundlett (Rangoon, Burma). Awards have also been made for papers read at students' meetings in London, or by students before meetings of local associations, as follows :The James Forrest Medal and a Miller Prize to Mr. D. J. Anderson (Glasgow), and Miller Prizes to Messrs. A. C. L. Browne (London), C. W. Scott (London), A. J. P. Pashler (Birmingham), W. D. MeFadyean (London), Granville Berry (London), P. J. Stuckey (Cardiff), W. H. Morgan (Newcastle), R. R. W. Grigson (London), E. A. Turner (London), and Frank Breakwell (London).

Applications are invited for the following appoint. ments, on or before the dates mentioned :- $\mathbf{A}$ University. lecturer and a University demonstrator in biochemistry at the University of CambridgeThe Professor, School of Biochemistry, Cambridge (Nov. 9). A junior assistant and guide-lecturer at the City of Birmingham Museum and Art GalleryThe Keeper (Nov. 11). An Armourers and Brasiers research fellow in metallurgy of the Royal SocietyThe Assistant Secretary, The Royal Society, Burlington House, W.1 (Nov. 14). A lecturer and tutor in hygiene in the Department of Education at the University of Bristol-The Secretary and Registrar (Nov. 19).

Erratum.-Letter on "Possible Existence of Multiply Charged Particles of Mass One" by Dr. M. Delbrück in NATURE for October $22:$ p. 627, col. 1, line 33, for "an $\alpha$-particle is stable ..." read "a particle in the $\alpha$-particle is stable. . . ."

No. 3287, VoL. 1301 